\title{
Difference in Surface Roughness of Ethylene-Vinyl-Acetate Sheet before and after Application of Finishing Liquid: Part 2 Changes over Time in Surface Roughness
}

\author{
Mutsumi Takahashi1 ${ }^{*}$, Yogetsu Bando ${ }^{2,3}$ \\ ${ }^{1}$ Department of Physiology, The Nippon Dental University School of Life Dentistry at Niigata, Niigata, Japan \\ ${ }^{2}$ Graduate School of Health and Sport Science, Nippon Sport Science University, Tokyo, Japan \\ ${ }^{3}$ Bando Dental Clinic, Ishikawa, Japan \\ Email: *mutsumit@ngt.ndu.ac.jp
}

How to cite this paper: Takahashi, M. and Bando, Y. (2019) Difference in Surface Roughness of Ethylene-Vinyl-Acetate Sheet before and after Application of Finishing Liquid: Part 2 Changes over Time in Surface Roughness. Materials Sciences and Applications, 10, 451-460.

https://doi.org/10.4236/msa.2019.106033

Received: May 9, 2019

Accepted: June 3, 2019

Published: June 6, 2019

Copyright $\odot 2019$ by author(s) and Scientific Research Publishing Inc. This work is licensed under the Creative Commons Attribution International License (CC BY 4.0).

http://creativecommons.org/licenses/by/4.0/

\begin{abstract}
Surface texture of the mouthguard affects the sense of adaptation in the athlete and further affects hygiene. The aim of this study was to investigate the changes over time in surface roughness after finish polishing of ethylene vinyl acetate (EVA) sheets and before and after finishing liquid application, and to evaluate its effectiveness. Total of 160 specimens of EVA $(3 \times 3 \mathrm{~mm})$ were divided into 4 groups according to polishing condition (control = unpolished; $\mathrm{RB}=$ Robinson-brush; LF = Lisko-Fine, and MW = Mouthguard-wheel). Polishing was performed at low speed by using a straight headpiece. The rotation speed was 5000, 4000 and $6000 \mathrm{rpm}$ for RB, LF, and MW, respectively. Next, a finishing liquid was applied to each specimen. Changes over time in surface roughness before and after application of the finishing liquid were compared by a non-contact surface shape measuring machine. The arithmetic average height $(\mathrm{Sa})$ was measured. The measurement time points were before application, immediately after application, and at 5, 10, and 15 min after application. The changes over time of the surface roughness of the sheet before and after application of the finishing liquid were analyzed by two-way analysis of variance and Bonferroni's multiple comparison tests. Surface roughness of the specimen before application became coarse in the order of control; MW, LF and RB, and $S a$ were about $0.21 \mu \mathrm{m}, 2.03 \mu \mathrm{m}, 2.94 \mu \mathrm{m}$, and $4.72 \mu \mathrm{m}$, respectively. That showed the same order after finishing liquid application. Significant decrease in $S a$ for RB and LF were seen at 10 min after application and at $5 \mathrm{~min}$ after application, respectively. $S a$ of MW was not significantly different before and after application. The results of this study showed that a
\end{abstract}


lubricity of about $1.0 \mu \mathrm{m}$ increases within 5 - $10 \mathrm{~min}$ of application of finishing liquid, but in cases where polishing was performed to about $2.0 \mu \mathrm{m}$; the application of finishing liquid has no effect.

\section{Keywords}

Mouthguard, Ethylene-Vinyl-Acetate, Surface Roughness, Polishing Method, Finishing Liquid, Changes over Time

\section{Introduction}

Wearing a mouthguard during sports reduces the risk of dental injury via absorbing impact forces, and the effectiveness and safety of the mouthguard are closely linked to the mouthguard material and thickness [1] [2] [3] [4] [5]. And, whether athletes can continue to use the mouthguard or not depends largely on the feeling of wearing, such as pronunciation and ease of breathing [6]. These problems can be solved as much as possible by making adjustments according to the oral condition of each athlete. In general, the surface characteristics of the apparatus installed intraoral affects hygiene factors, such as odor and coloring, in addition to sensory problems, such as wearing feeling and tongue feeling. So, the polished state is important to keep the mouthguard hygienic. Because the surface roughness of dental materials can directly influence bacterial adhesion, microorganisms adhere to irregular surfaces more easily [7] [8]. Furthermore, the long-term presence of microorganisms is a major cause of oral diseases such as gingivitis and dental caries. The presence of an oral infection during sports may have a negative impact on athletes [9].

Finishing methods for mouthguard materials include using silicone points and dedicated wheels, and using organic solvents, torches and hot air to melt the surface. Previously, we investigated the difference in surface roughness after finish polishing of ethylene vinyl acetate (EVA) sheets and after finishing liquid application. As a result, the surface roughness decreased due to the application of the finishing liquid when the surface roughness after finish polishing was about $2.0 \mu \mathrm{m}$ or more. However, the change over time after applying the finishing solution has not been clarified, and it is unclear how much smooth can be obtained. The aim of this study was to investigate the changes over time in surface roughness after finish polishing of EVA sheets and before and after finishing liquid application, and to evaluate its effectiveness.

\section{Materials and Methods}

Total of 160 specimens of EVA sheets (Sports Mouthguard', 4.0-mm-thick, clear; Keystone Dental Inc., Cherry Hill, NJ) measuring $3 \times 3 \mathrm{~mm}$ were obtained and divided into 4 groups according to polishing conditions; 1 ) unpolished (control), 2) polished using a Robinson-brush (No.11 soft, Buffalo Dental mfg. Co., Inc., Syosset, NY) (RB), 3) polished using a Lisko-Fine (No.11 soft, Buffalo Dental 
mfg. Co., Inc., Syosset, NY) (LF), and 4) polished using a Mouthguard-wheel (YAMAHACHI DENTAL MFG., CO., Aichi, Japan) (MW). For polishing, a straight headpiece was used, and polishing was performed at low speed until it covered the entire surface of the specimen. The rotation speed was based on the maximum rotation speed specified by the manufacturer. Maximum rotational speeds were 5000, 4000 and $6000 \mathrm{rpm}$ for RB, LF and MW, respectively. All specimens were prepared by one operator.

Next, a finishing liquid (Drufosoft finishing liquid, Dreve Dentamid, GmbH, Unna, Germany) was applied to each specimen. For application, a cotton swab was used, and it was applied by three reciprocations using light pressure. A non-contact surface shape measuring machine (CCI HD-XL, Taylor Hobson, Leicester, UK) was used for measuring surface roughness; the measurement range is $1.65 \mathrm{~mm}$ and the resolution is $0.01 \mathrm{~nm}$. The arithmetic average height ( $S a)$ was measured. Changes over time in surface roughness before and after application of the finishing liquid were compared. The measurement time point was before application, immediately after coating, and at 5, 10, and 15 min after coating. Application of the finishing liquid and measurement were carried out once for each specimen by one operator.

IBM SPSS 24.0 software (SPSS Japan Inc., Tokyo, Japan) was used for statistical analysis. The Shapiro-Wilk test for normality of distribution and Levene's test for homogeneity of variance were used to analyze the changes over time of the surface roughness of the EVA sheet before and after application of the finishing liquid. Normality and equality of variance were found for each item. There was no significance on Mauchly's sphericity test, so Greenhouse-Geisser correction was applied. All analyses were performed using repeated two-way analysis of variance and Bonferroni's post-hoc test. Significance was set to $\mathrm{p}<$ 0.05 , and the power was set to 0.8 for all analysis. Overall, a significant difference was considered to be present when both items were satisfied [10] [11].

\section{Results and Discussion}

Figure 1 shows surface texture images of the EVA sheet before and after application of the finishing liquid obtained by the non-contact surface shape measuring machine. Surface roughness of the specimen before application was in the order of control, MW, LF and RB. The surface roughness of the control specimen increased immediately after application of the finishing liquid but decreased with time, while the surface roughness of RB, LF and MW tended to decrease with time after application of the finishing liquid.

Two-way ANOVA results for the changes over time in surface roughness of the EVA sheets before and after application of the finishing liquid are summarized in Table 1. Simple main effect test was carried out because both the main effect and the interaction between measurement time point and sheet processing condition were significant.

Table 2 and Table 3 and Figure 2 show the results of multiple comparison test for sheet surface roughness depending on measurement time point and 


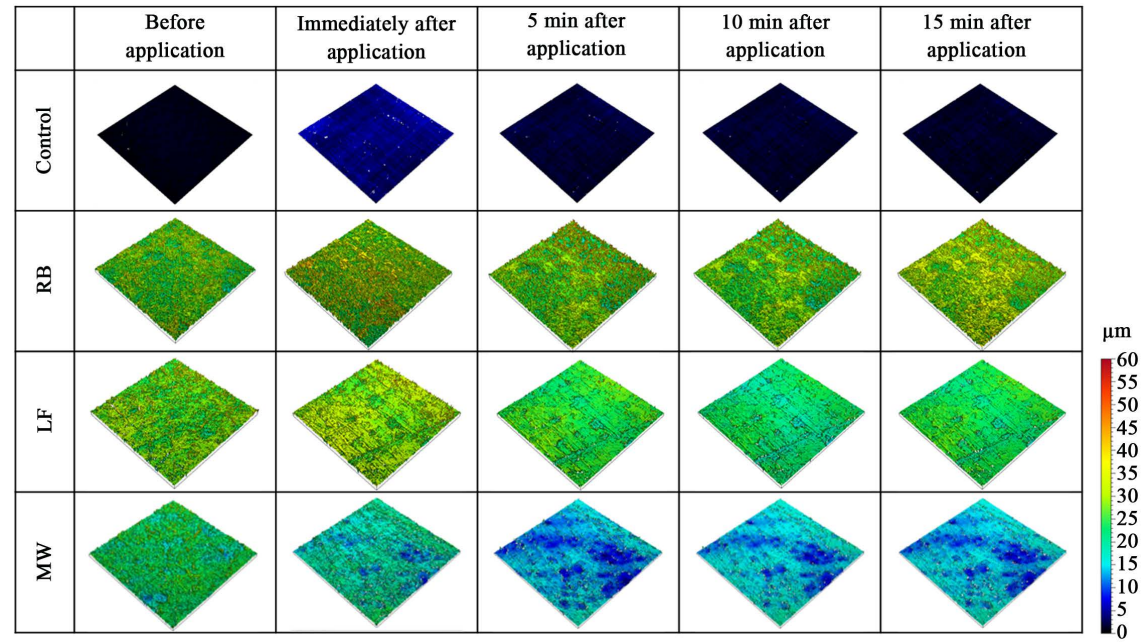

Figure 1. Surface texture image of EVA sheet by non-contact surface shape measuring machine. Measurement range; $0.83 \times 0.83 \mathrm{~mm}$, Objective lens; $\times 10$, Digital zoom; $\times 2$, Height scale; 0 - $60 \mu \mathrm{m}$.

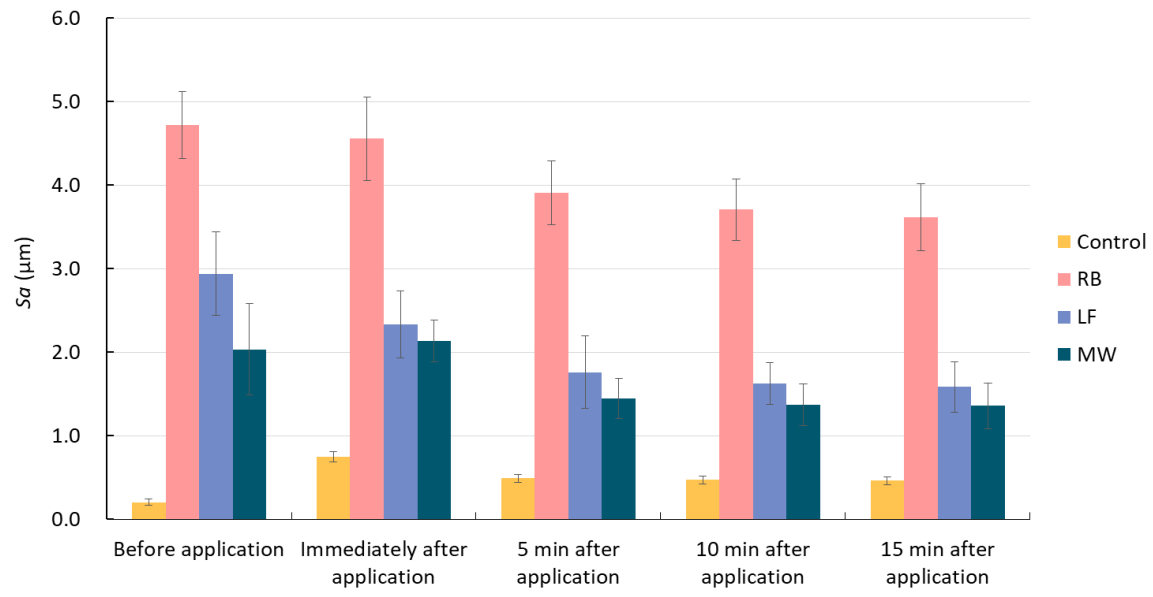

Figure 2. Comparison tests of surface roughness depending on measurement time point and sheet processing conditions

Table 1. Results of repeated two-way ANOVA for surface roughness.

\begin{tabular}{|c|c|c|c|c|c|}
\hline Source & SS & $d f$ & MS & F value & $P$ value \\
\hline \multicolumn{6}{|c|}{ Measurement time point } \\
\hline A & 24.266 & 2.022 & 12.001 & 112.912 & $<0.001^{\star *}$ \\
\hline Error (A) & 9.456 & 88.967 & 0.106 & & \\
\hline \multicolumn{6}{|c|}{ Processing condition } \\
\hline $\mathrm{B}$ & 409.761 & 3 & 136.587 & 237.509 & $<0.001^{\star *}$ \\
\hline$A * B$ & 12.842 & 6.066 & 2.117 & 19.918 & $<0.001^{\star *}$ \\
\hline Error (B) & 25.304 & 44 & 0.575 & & \\
\hline
\end{tabular}

SS: sum of squares. df: degree of freedom. MS: mean square. ${ }^{* *}$ : statistically significant, with $p<0.01$. 
Table 2. Results of Bonferroni's multiple comparison tests of surface roughness based on processing conditions.

\begin{tabular}{|c|c|c|c|c|}
\hline Before application & Control & $\mathrm{RB}$ & $\mathrm{LF}$ & MW \\
\hline \multicolumn{5}{|l|}{ Control } \\
\hline $\mathrm{RB}$ & ** & & & \\
\hline $\mathrm{LF}$ & ** & ** & & \\
\hline MW & ** & ** & n.s. & \\
\hline $\begin{array}{l}\text { Immediately } \\
\text { after application }\end{array}$ & Control & $\mathrm{RB}$ & $\mathrm{LF}$ & MW \\
\hline \multicolumn{5}{|l|}{ Control } \\
\hline $\mathrm{RB}$ & ** & & & \\
\hline $\mathrm{LF}$ & $* *$ & ** & & \\
\hline MW & ** & ** & n.s. & \\
\hline 5 min after application & Control & $\mathrm{RB}$ & $\mathrm{LF}$ & MW \\
\hline \multicolumn{5}{|l|}{ Control } \\
\hline $\mathrm{RB}$ & ** & & & \\
\hline $\mathrm{LF}$ & ** & $* *$ & & \\
\hline MW & ** & $* *$ & n.s. & \\
\hline 10 min after application & Control & $\mathrm{RB}$ & LF & MW \\
\hline \multicolumn{5}{|l|}{ Control } \\
\hline $\mathrm{RB}$ & $* *$ & & & \\
\hline $\mathrm{LF}$ & $* *$ & ** & & \\
\hline MW & ** & ** & n.s. & \\
\hline 15 min after application & Control & $\mathrm{RB}$ & $\mathrm{LF}$ & MW \\
\hline \multicolumn{5}{|l|}{ Control } \\
\hline $\mathrm{RB}$ & ** & & & \\
\hline $\mathrm{LF}$ & ** & $* *$ & & \\
\hline MW & ** & ** & n.s. & \\
\hline
\end{tabular}

sheet processing conditions. Sa before application increased in the order of control, MW, LF and RB, and showed the same order after coating. Sa of the control was less than $0.5 \mu \mathrm{m}$ at any measurement point. $S a$ of RB was about twice as high as MW and LF at any measurement point, and was as high as $3.5 \mu \mathrm{m}$ or more. There were no significant differences between MW and LF at any measurement time point. 
Table 3. Results of Bonferroni's multiple comparison tests of surface roughness based on measurement points.

\begin{tabular}{|c|c|c|c|c|c|}
\hline Control & $\begin{array}{c}\text { Before } \\
\text { application }\end{array}$ & $\begin{array}{l}\text { Immediately } \\
\text { after } \\
\text { application }\end{array}$ & $\begin{array}{l}5 \text { min after } \\
\text { application }\end{array}$ & $\begin{array}{l}10 \text { min after } \\
\text { application }\end{array}$ & $\begin{array}{l}15 \text { min after } \\
\text { application }\end{array}$ \\
\hline \multicolumn{6}{|l|}{$\begin{array}{c}\text { Before } \\
\text { application }\end{array}$} \\
\hline $\begin{array}{l}\text { Immediately } \\
\text { after application }\end{array}$ & ** & & & & \\
\hline $\begin{array}{l}5 \text { min after } \\
\text { application }\end{array}$ & $* *$ & $* *$ & & & \\
\hline $\begin{array}{l}10 \text { min after } \\
\text { application }\end{array}$ & $* *$ & $* *$ & n.s. & & \\
\hline $\begin{array}{l}15 \text { min after } \\
\text { application }\end{array}$ & $* *$ & ** & n.s. & n.s. & \\
\hline $\mathrm{RB}$ & $\begin{array}{c}\text { Before } \\
\text { application }\end{array}$ & $\begin{array}{l}\text { Immediately } \\
\text { after } \\
\text { application }\end{array}$ & $\begin{array}{l}5 \text { min after } \\
\text { application }\end{array}$ & $\begin{array}{l}10 \text { min after } \\
\text { application }\end{array}$ & $\begin{array}{l}15 \text { min after } \\
\text { application }\end{array}$ \\
\hline $\begin{array}{c}\text { Before } \\
\text { application }\end{array}$ & & & & & \\
\hline $\begin{array}{l}\text { Immediately } \\
\text { after application }\end{array}$ & n.s. & & & & \\
\hline $\begin{array}{l}5 \text { min after } \\
\text { application }\end{array}$ & n.s. & n.s. & & & \\
\hline $\begin{array}{l}10 \text { min after } \\
\text { application }\end{array}$ & ** & n.s. & n.s. & & \\
\hline $\begin{array}{l}15 \text { min after } \\
\text { application }\end{array}$ & ** & $* *$ & n.s. & n.s. & \\
\hline LF & $\begin{array}{c}\text { Before } \\
\text { application }\end{array}$ & $\begin{array}{l}\text { Immediately } \\
\text { after } \\
\text { application }\end{array}$ & $\begin{array}{l}5 \text { min after } \\
\text { application }\end{array}$ & $\begin{array}{l}10 \text { min after } \\
\text { application }\end{array}$ & $\begin{array}{l}15 \text { min after } \\
\text { application }\end{array}$ \\
\hline $\begin{array}{c}\text { Before } \\
\text { application }\end{array}$ & & & & & \\
\hline $\begin{array}{l}\text { Immediately } \\
\text { after application }\end{array}$ & n.s. & & & & \\
\hline $\begin{array}{l}5 \text { min after } \\
\text { application }\end{array}$ & ** & n.s. & & & \\
\hline $\begin{array}{l}10 \text { min after } \\
\text { application }\end{array}$ & $* *$ & $* *$ & n.s. & & \\
\hline $\begin{array}{l}15 \text { min after } \\
\text { application }\end{array}$ & $* *$ & $* *$ & n.s. & n.s. & \\
\hline
\end{tabular}




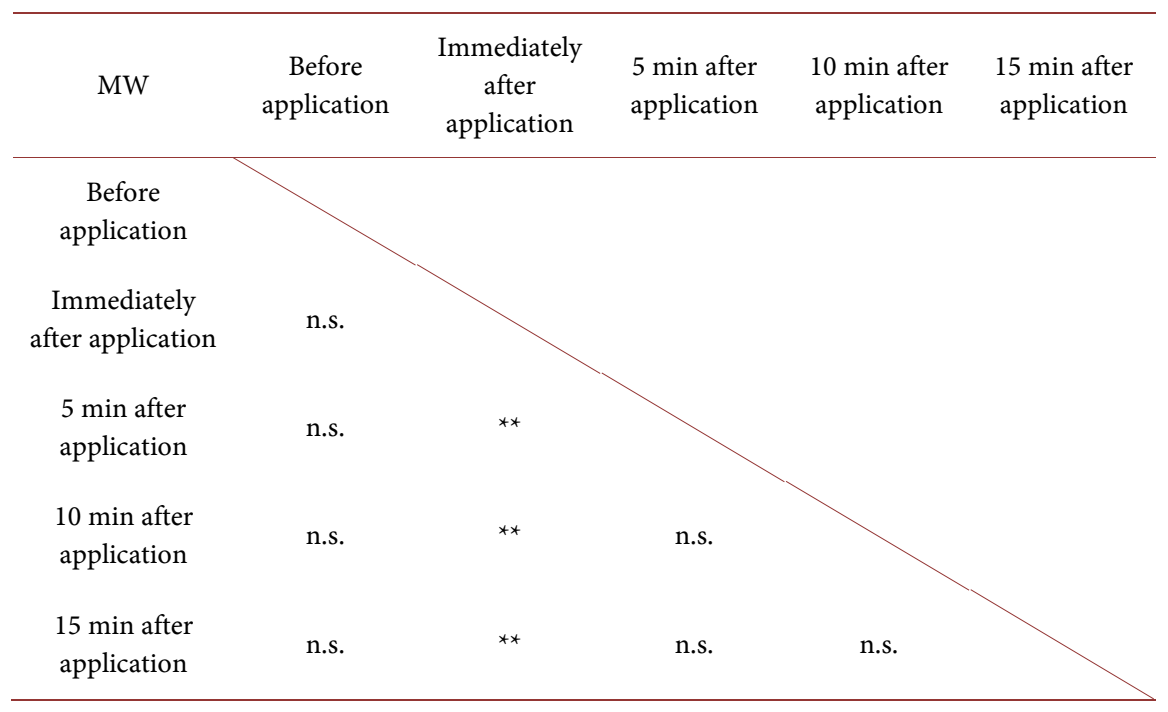

${ }^{* *} \mathrm{p}<0.01 ;$ n.s.: not significant.

Next, changes over time due to application of the finishing liquid were compared for each condition. $S a$ of the control increased immediately after application of the finishing liquid. Subsequently, Sa decreased, but at $15 \mathrm{~min}$ after application, it was larger than before application. $S a$ of RB decreased by about 1.0 $\mu \mathrm{m}$ at $10 \mathrm{~min}$ after coating than before application, but there was no statistical difference thereafter. Sa of LF decreased by about $1.2 \mu \mathrm{m}$ at $5 \mathrm{~min}$ after coating than before application, but there was no statistical difference thereafter. Sa of MW was not significantly different before and after coating.

Previously, as a polishing method of mouthguard, a method of polishing with a silicone point, dissolution with an organic solvent, and a method of softening a surface with a torch have been reported. More recently, urethane-type points, spongy wheels, hot air burners, liquid type polishes, etc. is commercially available. The process of finish polishing is extremely important, because the texture of the mouthguard affects the sense of adaptation of the athlete and also affects the hygiene [12]. Arithmetic average height ( $\mathrm{Sa}$ ) was used to evaluate the surface texture of the mouthguard in this study [13] [14] [15]. This is because the $S a$ is one scratch influence is very small with respect to the measured value, and stable results are obtained when the processing of the specimen is manually uneven as in this study [16].

The Sa before finishing liquid application for the original sheet (control) was about $0.21 \mu \mathrm{m}$. Roughness increased immediately after coating and then decreased with time, but at $15 \mathrm{~min}$ after application, it remained coarser (about $0.46 \mu \mathrm{m}$ ) than before application. Thus, lubricity equivalent to that of the original sheet cannot be obtained, even if finishing liquid is applied. In RB, Sa before application of finishing liquid showed a high value, which was about twice as high as LF and MW. After application of finishing liquid, the $S a$ of RB, LF and MW tended to decrease with time, but no differences were observed between the measurement times for MW. Significant decrease in $S a$ for RB and LF were seen at $10 \mathrm{~min}$ after application and at $5 \mathrm{~min}$ after application, respectively, and the 
$S a$ at this time showed decreases of about $1.01 \mu \mathrm{m}$ and about $1.18 \mu \mathrm{m}$ when compared with before application. The $S a$ at 15 min after application of RB, LF, and $\mathrm{MW}$ decreased compared to before application by about $1.10 \mu \mathrm{m}, 1.36 \mu \mathrm{m}$ and $0.68 \mu \mathrm{m}$, respectively. However, it was about $3.41 \mu \mathrm{m}, 1.38 \mu \mathrm{m}$ and $1.15 \mu \mathrm{m}$ higher than in controls before application. Thus, a lubricity of about $1.0 \mu \mathrm{m}$ can be obtained by applying finishing liquid as compared to the respective polished state. However, lubrication did not show a significant tendency to increase with application of finishing liquid when the lubricity after polishing is finely polished to about $2.0 \mu \mathrm{m}$ like MW. In addition, it was revealed that lubricity as high as the original cannot be obtained, even if finishing liquid is applied after polishing using various wheels. Therefore, this study suggested that when the degree of finish polishing is relatively coarse, a roughness of about $1.0 \mu \mathrm{m}$ can be significantly decreased within 5 - $10 \mathrm{~min}$ of application of the finishing liquid, and thereafter, roughness decreases gradually. On the other hand, although there were no statistically significant differences when finely polished, roughness showed a tendency to decrease somewhat by the application of finishing liquid.

In this research, in order to examine the effectiveness of the finishing liquid, the degree of surface roughness before and after application was compared over time. When the finishing liquid was applied after polishing, surface roughness decreased by about $1.0 \mu \mathrm{m}$ at 5 - $10 \mathrm{~min}$ after application. However, when surface roughness after polishing was about $2.0 \mu \mathrm{m}$, application of finishing liquid did not have a significant influence. In addition, even if finishing liquid was applied after polishing, lubricity comparable to the original sample was not obtained. In the future, it will be necessary to compare with finishing treatments with the hot air burner and differences when applying other finishing liquids.

\section{Conclusion}

In this study, we investigated the changes over time in surface roughness after finish polishing of EVA sheets and before and after finishing liquid application, and to evaluate its effectiveness. As the results suggested that a lubricity of about $1.0 \mu \mathrm{m}$ increases within $5-10 \mathrm{~min}$ of application of finishing liquid, and in cases where polishing was performed to about $2.0 \mu \mathrm{m}$, the application of finishing liquid has no effect. We are planning to analyze the element distribution of the surface in the future.

\section{Fund}

This study was supported by Nippon Dental University Intramural Research Fund.

\section{Conflicts of Interest}

The authors report no conflict of interest.

\section{References}

[1] Verissimo, C., Costa, P.V., Santos-Filho, P.C., Tantbirojn, D., Versluis, A. and Soares, C.J. (2016) Custom-Fitted EVA Mouthguards: What Is the Ideal Thickness? 
A Dynamic Finite Element Impact Study. Dental Traumatology, 32, 95-102. https://doi.org/10.1111/edt.12210

[2] Gialain, I.O., Coto, N.P., Driemeier, L., Noritomi, P.Y. and Dias, R.B. (2016) A Three-Dimensional Finite Element Analysis of the Sports Mouthguard. Dental Traumatology, 32, 409-415. https://doi.org/10.1111/edt.12265

[3] Bochnig, M.S., Oh, M.J., Nagel, T., Ziegler, F. and Jost-Brinkmann, P.G. (2017) Comparison of the Shock Absorption Capacities of Different Mouthguards. Dental Traumatology, 33, 205-213. https://doi.org/10.1111/edt.12324

[4] Gawlak, D., Mańka-Malara, K., Mierzwińska-Nastalska, E., Gieleta, R., Kamiński, T. and Łuniewska, M. (2017) A Comparison of Impact Force Reduction by Polymer Materials Used for Mouthguard Fabrication. Acta of Bioengineering and Biomechanics, 19, 89-95.

[5] Tribst, J.P.M., de Oliveira, Dal Piva, A.M., Borges, A.L.S. and Bottino, M.A. (2018) Influence of Custom-Made and Stock Mouthguard Thickness on Biomechanical Response to a Simulated Impact. Dental Traumatology, 34, 429-437. https://doi.org/10.1111/edt.12432

[6] Gawlak, D., Mierzwińska-Nastalska, E., Mańka-Malara, K. and Kamiński, T. (2015) Assessment of Custom and Standard, Self-Adapted Mouthguards in Terms of Comfort and Users Subjective Impressions of Their Protective Function. Dental Traumatology, 31, 113-117. https://doi.org/10.1111/edt.12132

[7] Kawai, K., Urano, M. and Ebisu, S. (2000) Effect of Surface Roughness of Porcelain on Adhesion of Bacteria and Their Synthesizing Glucans. Journal of Prosthetic Dentistry, 86, 664-667. https://doi.org/10.1067/mpr.2000.107442

[8] Leal, A., Paula, A., Ramalho, A., Esteves, M., Ferreira, M.M. and Carrilho, E. (2015) Roughness and Microhardness of Composites after Different Bleaching Techniques. Journal of Applied Biomaterials \& Functional Materials, 13, e381-e388. https://doi.org/10.5301/jabfm.5000239

[9] Needleman, I., Ashley, P., Petrie, A., Fortune, F., Turner, W., Jones, J., Niggli, J., Engebretsen, L., Budgett, R., Donos, N., Clough, T. and Porter, S. (2013) Oral Health and Impact on Performance of Athletes Participating in the London 2012 Olympic Games: A Cross-Sectional Study. Journal of Sports Medicine, 47, 1054-1058. https://doi.org/10.1136/bjsports-2013-092891

[10] Takahashi M, Bando Y. (2018) Effect of the Anteroposterior Position of the Model on Fabricated Mouthguard Thickness: Part 2 Influence of Sheet Thickness and Material. Dental Traumatology, 34, 370-377. https://doi.org/10.1111/edt.12423

[11] Takahashi, M. and Bando, Y. (2018) Thermoforming Method to Effectively Maintain Mouthguard Thickness: Effect of Moving the Model Position Just before Vacuum Formation. Dental Traumatology, 35, 121-127.

https://doi.org/10.1111/edt.12447

[12] Almeida, M.H., Ceschim, G.V., Ioriom, N.L.P.P., Póvoa, H.C.C., Cajazeira, M.R.R., Guimarães, G.S, Antunes, L.S. and Antunes, L.A.A. (2018) Influence of Thickness, Color, and Polishing Process of Ethylene-Vinyl-Acetate Sheets on Surface Roughness and Microorganism Adhesion. Dental Traumatology, 34, 51-57. https://doi.org/10.1111/edt.12374

[13] Sul, Y.T., Kang, B.S., Johansson, C., Um, H.S., Park, C.J. and Albrektsson, T. (2009) The Roles of Surface Chemistry and Topography in the Strength and Rate of Osseointegration of Titanium Implants in Bone. Journal of Biomedical Materials Research Part A, 89, 942-950. https://doi.org/10.1002/jbm.a.32041

[14] Koshihara, T., Hara, M., Sato, T., Hayashibara, T., Masuda, T. and Shinya, A. (2016) 
Evaluation of the Surface Texture of CAD/CAM-Produced Crowns among Various Types of CAD/CAM Milling Systems. The Shikwa Gakuho, 116, 149-153.

[15] Takahashi, M. and Bando Y. (2018) Difference in Surface Roughness of Ethylene-Vinyl-Acetate Sheet before and after Application of Finishing Liquid. Materials Sciences and Applications, 9, 985-992. https://doi.org/10.4236/msa.2018.913071

[16] Olympus Scientific Solutions Americas Corp. Height Parameters (Amplitude Mean in the Height Direction).

https://www.olympus-ims.com/en/knowledge/metrology/roughness/3d_parameter/ 